\title{
The Qualitative Analysis of Factors Influencing the Adoption Rate of Reward-Based Crowdfunding by Polish Filmmakers
}

\author{
Urszula Świerczyńska-Kaczor \\ Matgorzata Kotlińska** \\ Monika Żelazowska ${ }^{\star \star \star}$
}

\begin{abstract}
The aim of this article is to analyze and discuss the factors impacting the process of the implementation of crowdfunding by the Polish film industry. The presented study is based on the qualitative approach: unstructured or semi-structured interviews, questionnaires and the analysis of case studies. The respondents enumerated and evaluated a wide spectrum of factors facilitating and hindering the adoption rate: from general barriers (e.g. legal regulation of crowdfunding) to very specific aspects for filmmaking (e.g. the unprofessional promotional video of the crowdfunding project). The findings highlighted the significance of the following factors: the existing strong filmmakers' attitude that 'crowdfunding is for film beginners', the complexity of team management (film crew) during the process of crowdfunding campaigns, and the cultural aspects of seeking financial support from friends.
\end{abstract}

Keywords: the film funding innovation, the crowdfunding project, the film financing.

* Państwowa Wyższa Szkoła Filmowa, Telewizyjna i Teatralna w Łodzi, Wydział Organizacji Sztuki Filmowej

** Uniwersytet Łódzki, Wydział Zarządzania.

*** Państwowa Wyższa Szkoła Filmowa, Telewizyjna i Teatralna w Łodzi, Wydział Organizacji Sztuki Filmowej. 


\section{Introduction}

Crowdfunding can be explained as an e-service offered by a crowdfunding platform, which works as an intermediary between the entity seeking for financial support (the founder/the crowdfunding project creator) and the funder (the backer/the investor/the sponsor). However, the functions of crowdfunding go beyond 'just financing the project' and involve the promotion and building of customer interest, pre-ordering of the product, or the validation of the concept presented in the crowdfunding campaign ${ }^{1}$.

In this article we focus on the analysis of the factors which facilitate and hinder the adoption rate of reward-based crowdfunding by the Polish film industry. Although in 2017 the Polish crowdfunding market was valued PLN 200 million with predicted further growth ${ }^{2}$, the scope of research about the Polish crowdfunding market is still very limited ${ }^{3}$. This article aims (at least) to partly fill this gap, contributing to the better understanding of new possibilities and challenges for the projects lying within the overlapping field of the film industry and crowdfunding.

The article starts with the presentation of the research problem, which is followed by the presentation of the empirical study methodology and the discussion of the results. The article ends with conclusions, the limitations of the study, and future research.

1 E. Mollick, The dynamics of crowdfunding: An exploratory study, "Journal of Business Venturing" 2014, vol. 29, issue 1, pp. 1-16; J. Hörisch, Crowdfunding for environmental ventures: an empirical analysis of the influence of environmental orientation on the success of crowdfunding initiatives, "Journal of Cleaner Production" 2015, vol. 107, pp. 636-645.

2 Money.pl,Zrzutka.pl: Rynek crowdfundingu przekroczy 0,5 mld złw 2018 r., published: 06.02.2018, https://www.money.pl/gielda/wiadomosci/artykul/zrzutka-pl-rynek-crowdfundinguprzekroczy,144,0,2397840.html [accessed 1.04.2018].

3 The following publications can be pointed to as examples of research relevant to the Polish market: K. Kozioł-Nadolna, Crowdfunding jako źródło finansowania innowacyjnych projektów, „Zeszyty Naukowe Uniwersytetu Szczecińskiego. Finanse, Rynki Finansowe, Ubezpieczenia” 2015, nr 73 (Ryzyko, zarządzanie, wartość), pp. 671-683; D. Kordela, Crowdfunding w Polsce - koncepcja finansowania społecznościowego, „Prace Naukowe Uniwersytetu Ekonomicznego we Wrocławiu" 2016, nr 436 (Rachunkowość na rzecz zrównoważonego rozwoju. Gospodarka - etyka - środowisko), pp. 143-153; U. Świerczyńska-Kaczor, P. Kossecki, The Role of Polish Crowdfunding Platforms in Film Productions - an Exploratory Study, „Proceedings of the 2016 Federated Conference on Computer Science and Information Systems, Annals of Computer Science and Information Systems" 2016, vol. 8, pp. 1289-1296. 


\section{The research problem}

In our study, we focus on reward-based crowdfunding, which can be identified as a distinct business model ${ }^{4}$ or can be perceived as a sub-type of donation-based crowdfunding. In reward-based crowdfunding the sponsor (backer) pledges a specified amount of money to the project founder and in return a backer expects to receive a specified type of reward (e.g. the future product, gadgets, or social recognition). This type of crowdfunding is more aligned to patronage, sponsorship or community building rather than having an investment focus ${ }^{6}$, and in some cases the roles between the project founder and the backer are reversible (meaning that the backer can become the founder of a project, and the founder is often a backer for other projects $\left.{ }^{7}\right)$. Although the value of the rewards is sometimes purely symbolic (e.g. 'virtual hug', 'eternal gratitude for support'), the reward-based crowdfunding differs from a donation to charitable causes ${ }^{8}$. Crowdfunded film-projects are mostly listed on the reward-based crowdfunding platform ${ }^{9}$, although not exclusively (some film-projects are listed on the investment-type crowdfunding $\left.{ }^{10}\right)$. 'Film' is often the leading category on reward-based crowdfunding platforms ${ }^{11}$. The higher popularity of a film-project compared to other categories can be explained by various reasons:

- the crowdfunding campaign is suitable for different phases of film production (the film development, the film production - film shooting and film postproduction);

4 See the classification presented in e.g. P. Belleflamme, N. Omrani, M. Peitz, The Economics of Crowdfunding Platforms, "Information Economics and Policy" 2015, vol. 33, pp. 11-28; G. A. Gabison, Crowdfunding and its Regulation. How can Crowdfunding help ICT Innovation?, European Commission, EUR 26992 EN - Joint Research Centre - Institute for Prospective Technological Studies, 2015.

5 D. T. Dziuba, Rozwój systemów crowdfundingu - modele, oczekiwania i uwarunkowania, „Problemy Zarządzania” 2012, vol. 10, nr 3 (38), pp. 83-103.

6 M. Kuti, G. Madarász, Crowdfunding, "Public Finance Quarterly" 2014, vol. 59, issue 3, pp. 355-366; E. Kirby, S. Worner, Crowd-funding: An Infant Industry Growing Fast, Staff Working Paper of the IOSCO Research Department [SWP3/2014], 2014.

7 K. André, S. Bureau, A. Gautier, O. Rubel, Beyond the Opposition Between Altruism and Selfinterest: Reciprocal Giving in Reward-Based Crowdfunding, "Journal of Business Ethics" 2017, vol. 146, issue 2, pp. 313-332.

8 For example, the crowdfunding platforms polakpotrafi, or Kickstarter regulations forbid listing charity projects.

9 For example, Kickstarter, Indiegogo, Ulule, the Polish platform polakpotrafi.pl

10 For example, the supernatural thriller 'The Sleeping Room' was funded on the equity-based crowdfunding platform Seedrs.com - see: Crowdfunding platform Seedrs, https://www. seedrs.com/the-sleeping-room1 [accessed 23.04.2018].

11 For example, in April 2018 on Kickstarter, 'film and video' category attracted the highest number of projects - Crowdfunding platform Kickstarter, https://www.kickstarter.com/ [accessed 23.04.2018]. 
- film projects seldom raise concerns about the risk of the intellectual property infringement (contrary to, for example, some technology projects which may disclose the know-how);

- the filmmaker can attract a future audience during the crowdfunding campaign, and therefore crowdfunding can increase future demand for the final product: DVD film or online film viewing.

So far, factors impacting the process of the adoption of crowdfunding by the film industry, and by the Polish film industry particularly, have attracted little attention in research literature. The study of U. Świerczyńska-Kaczor and P. Kossecki (2016) indicated some barriers to crowdfunding implementation on the Polish market, for example the sponsor's uncertainty about the process of the project execution (whether the film will be produced, or money will be spent properly), the lack of trust and knowledge of Polish filmmakers, and unclear legal regulations ${ }^{12}$. In this article, we extend the scope of the previous research by analyzing a broader catalog of factors which impact the adoption rate of crowdfunding by filmmakers. Moreover, as the study of U. Świerczyńska-Kaczor and P. Kossecki was conducted in 2016, we can also compare our current results with those obtained by researchers two years ago.

In the process of designing the research, we implemented the theoretical framework based on the Roger's Diffusion of Innovation ${ }^{13}$, Technology Acceptance Model $^{14}$, and UTAUT - Unified Theory of Acceptance and Use of Technology ${ }^{15}$. With reference to this theoretical background, we aim to investigate the following research problems:

- What are the relative advantages of crowdfunding with comparison to the existing solutions? This area is also linked to the perceived usefulness of new technology and a perceived usefulness of a particular platform (as for example, the usefulness of the global crowdfunding platform Kickstarter can be evaluated differently than local platforms);

- What is the level of the compatibility of crowdfunding with existing values, past experiences, and needs of filmmakers?

- How does the complexity of such innovation as the film crowdfunding affect the process of the diffusion? This area covers both technological issues (e.g. how to set up a crowdfunding project, how to develop the reward tiers, how to attract the potential backers to the film project) and legal issues connected with film crowdfunding projects. The complexity of innovation also includes the film project founders' perception of cooperation with the team engaged in the crowdfunding.

12 U. Świerczyńska-Kaczor, P. Kossecki, op. cit.

13 E. M. Rogers, Diffusion of Innovations, 5th ed., Free Press, 2003.

14 F. D. Davis, R. P. Bagozzi, P. R. Warshaw, User Acceptance of Computer Technology: A Comparison of Two Theoretical Models, "Management Science" 1989, vol. 35, no. 8, pp. 982-1003.

15 V. Venkatesh, M. G. Morris, G. B. Davis, F. D. Davis, User Acceptance of Information Technology: Toward a Unified View, "MIS Quarterly” 2003, vol. 27, no. 3, pp. 425-478. 
- Do the trialability and observability of crowdfunding have an impact on the process of adoption by potential filmmakers?

- What factors may moderate the impact on the actual usage of innovation? In this area we focus for example, on the experience of the filmmaker, both in crowdfunding and the film production, the possibilities for receiving financial support by the filmmaker through other sources.

\section{The methodology of the study}

The research questions specified above were addressed in the empirical study conducted in March and April in 2018. The study was based on the qualitative approach of collecting data, and included the following methods:

- collecting data through the interviews and through the semi-structured questionnaires;

- collecting data from the crowdfunding case studies of seven films and one theater performance;

- collecting publicly available data about the film projects on crowdfunding platforms;

The respondents were 40 individuals (25 women, 15 men) - the project founders or potential project founders - and they were mostly film students who are also often actively involved in the film market either as film producers, film production managers, directors of photography or screenwriters. Taking into account the students' voice about crowdfunding was especially important as the student segment is more likely to be interested in crowdfunding as an alternative approach for seeking film funding in comparison to the experienced professionals in the film industry.

\section{Results and discussion of results}

\section{A. Perceived usefulness of crowdfunding and its compatibility with values and experiences}

Among the factors indicated by respondents as impacting the implementation of crowdfunding (see: Table 3), the perception of crowdfunding as 'for the beginners in filmmaking' turned out to be the one of major importance. Respondents emphasized that although they perceived crowdfunding as a tool 'with huge potential and 
usefulness', its usefulness is limited to small film projects. Half of respondent group (50\%) also stated that if a global platform such as Kickstarter were open for Polish founders, the crowdfunding would be more a useful in film projects ${ }^{16}$.

The potential usefulness of crowdfunding for the film professionals should be evaluated in comparison to traditional sources of funding. So far, the Polish Film Institute (PISF) has played a crucial role in the process of film making. In 2016, PISF subsidies for the film production reached the budget PLN 111 million - about USD\$ 32.5 million $^{17}$. Although the received subsidies vary between projects, in some cases the financial support for a feature film production reaches budgets in the millions ${ }^{18}$. However, the budgets and the subsidies for documentary films are much more modest. To put the financial aspects into perspective, we compared the selected descriptive statistics both for the film projects listed on the crowdfunding platform Kickstarter and the PISF funding (Table 1, Table 2):

- The descriptive statistics of 100 film projects active on 28 March on Kickstarter ${ }^{19}$ within the different film genre (for example, shorts, documentaries, the feature film) indicate that although almost half of sampled film projects aimed to the financial threshold below USD\$ 5000 , over $20 \%$ of projects aimed above the USD\$ 20000 (Table 2).

- The descriptive statistics of documentaries within the (mentioned above) sample of 100 film projects indicate that in this sub-sample the average aimed financial threshold was about USD $\$ 22200$, and the average achieved funding at the moment of sampling was about USD\$ 17000 (Table 1).

- The structure of financing for the 15 projects of documentaries recommended for production by PISF in April 2017 (Table 1) points out that the average received funding was over USD $\$ 46000$, but the minimum funding was about USD $\$ 12000$, and over one in three projects received a subsidy below USD\$ 50000 .

The overview of funding illustrates that although the segment of very small film projects (below USA $\$ 10000$ ) dominated among crowdfunding projects, at least in some cases, the crowdfunding projects reached the funding level which is comparable to the financial subsidies available from PISF. However, the level of financing on Polish crowdfunding platforms, e.g. polakpotrafi.pl, wspieramkulture. $\mathrm{pl}$, is much lower compared to Kickstarter ${ }^{20}$.

16 Up till now, the project creation option on Kickstarter is available for residents in some European Union countries (e.g. Sweden, Germany, France), but not in Poland - Crowdfunding platform Kickstarter, https://www.kickstarter.com/ [accessed 16.03.2018].

17 Polish Film Institute, PISF, https://www.pisf.pl/ [accessed 15.03.2018].

18 For example, in 2017 the feature film "Łuma" received a PLN 3.5 million subsidy/about USD\$ 1 million, or the feature film "Pan T." PLN 2.5 million/about USD\$ 0.731 million - Polish Film Institute, PISF, https://www.pisf.pl/ [accessed 15.03.2018].

19 We excluded projects with zero funding at the moment of sampling.

20 See the previous research published in: U. Świerczyńska-Kaczor, P. Kossecki, op. cit. 
In the presented study, the low level of potential financing was the respondents' argument for supporting the notion that 'crowdfunding is mostly for beginners in filmmaking'. This notion was also reinforced by the respondents' perception of crowdfunding as a competition in which the professional projects may not attract the backers' attention which they deserve. The respondents pointed out that the unexperienced filmmakers have a lower chance to receive funds by the traditional way, so they turn to crowdfunding, but these projects are more risky film productions (as the filmmakers are unexperienced, not only in the film production, but also in the crowdfunding processes). It succeeds that the probable failures (especially, in the film delivery or good quality film delivery) lower the potential backers' intention for supporting other film projects, including the projects created by film professionals.

Table 1. The descriptive statistics illustrating the selected aspects of documentary film production

\begin{tabular}{|c|c|c|c|}
\hline \multicolumn{2}{|c|}{$\begin{array}{l}\text { The descriptive statistics for the } 15 \\
\text { projects of documentaries recommended } \\
\text { for production by PISF in April } 2017 \\
\text { (data in PLN changed into USD\$) }\end{array}$} & \multicolumn{2}{|c|}{$\begin{array}{c}\text { The descriptive statistics for } 22 \text { projects } \\
\text { categorized as documentary within the } \\
\text { film and video category at Kickstarter, } \\
\text { sampled in March } 2018\end{array}$} \\
\hline 1 & 2 & 3 & 4 \\
\hline $\begin{array}{l}\text { The average film } \\
\text { budget }\end{array}$ & about USD\$ 110000 & $\begin{array}{l}\text { The average financial } \\
\text { threshold set as goal }\end{array}$ & $\begin{array}{c}\text { USD\$ } 22289 \\
\text { Minimum: USD } 825 \\
\text { Maximum: USD } 75000\end{array}$ \\
\hline $\begin{array}{l}\text { The average financial } \\
\text { subsidy applied to } \\
\text { PISF }\end{array}$ & about USD\$ 57500 & $\begin{array}{l}\text { The average received } \\
\text { funding at the mo- } \\
\text { ment of sampling }\end{array}$ & $\begin{array}{c}\text { USD\$ } 17014 \\
\text { Minimum: USD\$55 } \\
\text { Maximum: USD\$75096 }\end{array}$ \\
\hline $\begin{array}{l}\text { The average financial } \\
\text { subsidy received }\end{array}$ & about USD\$ 46800 & $\begin{array}{c}\text { The average number } \\
\text { of backers }\end{array}$ & 157 \\
\hline $\begin{array}{l}\text { The minimum } \\
\text { received subsidy by } \\
\text { a project }\end{array}$ & about USD\$ 11700 & $\begin{array}{l}\text { The average support } \\
\text { for backer }\end{array}$ & USD\$ 100 \\
\hline $\begin{array}{l}\text { The maximum } \\
\text { received subsidy by } \\
\text { a project }\end{array}$ & about USD\$ 64400 & $\begin{array}{l}\text { The \% of projects } \\
\text { aiming up to } \\
\text { USD\$9999 }\end{array}$ & $45.5 \%$ \\
\hline $\begin{array}{l}\text { The percentage of } \\
\text { projects with subsi- } \\
\text { dies below } \\
\text { USD\$ } 30000\end{array}$ & $20 \%$ & $\begin{array}{l}\text { The } \% \text { of projects } \\
\text { aiming } \\
\text { USD\$ } 10000-49999\end{array}$ & $36.4 \%$ \\
\hline
\end{tabular}


Table 1 (contd)

\begin{tabular}{|l|c|c|c|}
\hline \multicolumn{1}{|c|}{1} & 2 & 3 & 4 \\
\hline $\begin{array}{l}\text { The percentage of } \\
\text { projects with subsidies } \\
\text { USD\$ } 30001-50000\end{array}$ & $13 \%$ & $\begin{array}{c}\text { The \% of projects } \\
\text { aiming } \\
\text { USD\$50 000 and over }\end{array}$ & $18.2 \%$ \\
\hline $\begin{array}{l}\text { The percentage } \\
\text { of projects with } \\
\text { subsidies } \\
\text { USD\$50 00-100 000 }\end{array}$ & $67 \%$ & & \\
\hline
\end{tabular}

Source: analysis based on data published on Polish Film Institute, PISF: https://www.pisf.pl/ dotacje/dofinansowane-projekty/2017/po-produkcja-filmowa/priorytet-4-filmy-dokumentalnesesja-1-2017) [accessed 15.03.2018] and the authors' own analysis based on the obtained sample.

Table 2. The descriptive statistics of sampled 100 active projects within the category 'film and video' on Kickstarter in March 2018

\begin{tabular}{|c|c|c|c|c|c|}
\hline & $\begin{array}{l}\text { The financial } \\
\text { goal (aimed } \\
\text { threshold) for } \\
\text { a project is } \\
\text { within a bracket } \\
\text { [in USD\$] }\end{array}$ & $\begin{array}{c}\% \text { of } \\
\text { sampled } \\
\text { projects } \\
\text { with } \\
\text { funding } \\
\text { goal } \\
\text { within the } \\
\text { indicated } \\
\text { bracket }\end{array}$ & $\begin{array}{l}\text { The avera- } \\
\text { ge received } \\
\text { funding } \\
\text { at the } \\
\text { moment of } \\
\text { sampling } \\
\text { [in USD\$] }\end{array}$ & $\begin{array}{c}\text { The } \\
\text { average } \\
\text { numbers of } \\
\text { backers for } \\
\text { a project }\end{array}$ & $\begin{array}{l}\% \text { of } \\
\text { projects } \\
\text { which } \\
\text { reached } \\
\text { the funding } \\
\text { goal at the } \\
\text { moment } \\
\text { of sampling }\end{array}$ \\
\hline \multirow{7}{*}{$\begin{array}{l}\text { Sampled 'live' } \\
\text { projects } \\
\text { ( } n=100 \text { ) different } \\
\text { categories, } \\
\text { e.g.: documenta- } \\
\text { ry, drama, shorts, } \\
\text { general 'film and } \\
\text { video'. }\end{array}$} & 0-999 & 11.0 & 370 & 10 & 36.4 \\
\hline & $1000-4999$ & 38.0 & 1494 & 26 & 15.8 \\
\hline & $5000-9999$ & 17.0 & 3146 & 38 & 23.5 \\
\hline & $10000-19999$ & 13.0 & 9459 & 99 & 30.8 \\
\hline & $20000-49999$ & 14.0 & 19767 & 241 & 28.6 \\
\hline & 50 000-99 999 & 5.0 & 46565 & 302 & 40.0 \\
\hline & 100000 and over & 2.0 & 64795 & 1484 & 0.0 \\
\hline
\end{tabular}

Source: authors' own analysis. 
Table 3. Selected factors impacting the implementation of crowdfunding by Polish film industry as indicated by respondents

\begin{tabular}{|c|c|}
\hline \multirow[t]{2}{*}{$\begin{array}{l}\text { Factors connected with the } \\
\text { crowdfunding platforms }\end{array}$} & $\begin{array}{l}\text { There is no crowdfunding platform on Polish market which } \\
\text { specializes in film production }\end{array}$ \\
\hline & $\begin{array}{l}\text { Polish filmmakers cannot use global crowdfunding } \\
\text { platform Kickstarter for opening their own project }\end{array}$ \\
\hline \multirow[t]{2}{*}{ Factors connected with backers } & $\begin{array}{l}\text { Polish potential backers do not have sufficient knowledge } \\
\text { about crowdfunding }\end{array}$ \\
\hline & $\begin{array}{l}\text { The sponsor's distrust whether the film will be produced at } \\
\text { all }\end{array}$ \\
\hline \multirow[t]{8}{*}{$\begin{array}{l}\text { Factors connected with the film } \\
\text { project founder }\end{array}$} & $\begin{array}{l}\text { The perception of innovation as 'the crowdfunding is for } \\
\text { beginners in filmmaking' }\end{array}$ \\
\hline & $\begin{array}{l}\text { Crowdfunding is difficult for professionals as they have } \\
\text { to compete with both professionals and unprofessional } \\
\text { filmmakers and overcome sponsors' uncertainty about the } \\
\text { possible lack of quality of film product }\end{array}$ \\
\hline & $\begin{array}{l}\text { Polish directors/producers do not have sufficient } \\
\text { knowledge about crowdfunding (how platforms operate, } \\
\text { legal regulation, differences between platforms) }\end{array}$ \\
\hline & $\begin{array}{l}\text { The differences between the producers and directors about } \\
\text { the crowdfunding (the functions of crowdfunding, the } \\
\text { possibilities of implementation) }\end{array}$ \\
\hline & $\begin{array}{l}\text { The managerial challenges (problems, conflicts) with team } \\
\text { engaged with the crowdfunding }\end{array}$ \\
\hline & $\begin{array}{l}\text { How to ask friends for financial support? - the possible } \\
\text { cultural, psychological barriers }\end{array}$ \\
\hline & $\begin{array}{l}\text { The crowdfunding demands different skills and abilities } \\
\text { than 'pure filmmaking' from a filmmaker }\end{array}$ \\
\hline & $\begin{array}{l}\text { The mistakes in the design of crowdfunding project account } \\
\text { (see: Table 4) }\end{array}$ \\
\hline
\end{tabular}

Source: authors' own analysis.

\section{B. The complexity of innovation: the lack of knowledge about crowdfunding}

Both the founders (film producers, film directors) and the potential sponsors were indicated by respondents as parties which do not have sufficient knowledge about crowdfunding. The lack of knowledge may refer to different aspects: the parties do not know how crowdfunding platforms work, what kind of legal regulations apply 
to crowdfunding on the Polish market (including tax systems), and the differences between platforms.

Although only $48 \%$ of our respondents directly indicated unclear legal regulations as factor hindering the crowdfunding implementation, other factors indicated by respondents are also connected with legal aspects. For example, the sponsor's uncertainty whether the film will be produced at all lies in the scope of legal regulation of contracts between the sponsor and the founder, or the sponsors' unwillingness to share the data with crowdfunding platform is linked to the personal legal data protection. Our analysis of the terms of services of selected Polish crowdfunding platforms (polakpotrafi.pl, wspiramkulture.pl, wspieram. to) indicated that the crowdfunding platforms do not take responsibility whether the rewards (e.g. film on DVD) would be delivered by the project founder to the sponsor, or whether the project will be executed at all. The crowdfunding platforms also do not take responsibility for supervising the execution of the projects ${ }^{21}$.

\section{The complexity of innovation: the lack of proper project management in the crowdfunding project}

Other factors indicated by the filmmakers lie in the area of the challenges connected with the team management: the conflict management, the workload between the team members, and the team leader's approach to project management. In this article, we would like to point to the following exemplary factors (as the detailed analysis of these group of factors is beyond the scope of this article):

- In many cases the team members involved in the crowdfunding project are also involved in other tasks. This problem can be clearly illustrated by the following respondent's statement: the crowdfunding project was for art and an artistic film, we all have full time jobs.

- The filmmakers face new challenges, not connected with filmmaking, but with the procedures of crowdfunding. For example, the majority of respondents stated that the costs connected with the production and delivery of rewards would be difficult to properly evaluate.

21 Although the contract between the project founder and the backer is an innominate contract within the Polish law, other regulations can be applied per analogia (for example contract for services, contract for the completion of specific tasks). The reward-based crowdfunding platforms are also obliged to follow Polish and European Union legal regulations, for example, the act on providing electronic services, Polish Civil Code and the legal regulation about the protection of personal data, particularly the following legal regulations: Ustawa z dnia 18 lipca 2002 r. o świadczeniu usług drogą elektroniczną, Dz.U. 2002, Nr 144, poz. 1204 and Regulation (EU) 2016/679 of the European Parliament and of the Council of 27 April 2016 on the protection of natural persons with regard to the processing of personal data and on the free movement of such data, and repealing Directive 95/46/EC (General Data Protection Regulation), Official Journal of the European Union, 2016.119.1 
- The cooperation between the film producer and the film director in the process of management of crowdfunding project was often evaluated by respondents as difficult, leading to conflicts both on professional and personal levels (the founders of the crowdfunding projects are usually the producers or film directors).

- In some cases, the multiple roles played by the project founder on one project - as the film director, the film producer, or even the screenwriter - negatively impact project management.

\section{The complexity of crowdfunding: what went wrong? Filmmakers' mistakes in the design of crowdfunding film project websites}

The literature studies indicated that many factors directly or indirectly contribute to reaching the funding goal in a crowdfunding campaign or influence the sponsor's satisfaction, for example: the level of funding goal, the project time duration, the level-reward structure and the types of rewards, the promotional video, dialog built through the comments and replies ${ }^{22}$.

In our study, the respondents indicated the following aspects, linked to the crowdfunding account, which hinder the process of gathering funds: the unprofessional video, vague information about budget spending, the lack of rewards which can attract the sponsors, the lack of a project 'selling point' meaning the aspect which distinguishes the project from other projects, the lack of famous people involved in the project, and the high threshold level for film funding (Table 4). All of the above-mentioned elements possibly contribute to the respondents' perception that most Polish film projects do not engender trust in the backers. The selected mistakes indicated by respondents are discussed below.

1. The respondents indicated that the film project campaigns often fail to engender trust in the backer.

22 See for example: D. Frydrych, A. J. Bock, T. Kinder, B. Koeck, Exploring entrepreneurial legitimacy in reward-based crowdfunding, "Venture Capital. An International Journal of Entrepreneurial Finance" 2014, vol. 16, issue 3, pp. 247-269; A. Cordova, J. Dolci, G. Gianfrate, The Determinants of Crowdfunding Success: Evidence from Technology Projects, "Procedia - Social and Behavioral Sciences" 2015, vol. 181, pp. 115-124; N. Steigenberger, Why supporters contribute to rewardbased crowdfunding, "International Journal of Entrepreneurial Behavior \& Research" 2017, vol. 23, issue 2, pp. 336-353; C. Thürridl, B. Kamleitner, What Goes around Comes Around? Rewards as Strategic Assets in Crowdfunding, "California Management Review" 2016, vol. 58, issue 2, pp. 88-110; N. Wang, Q. Li, H. Liang, T. Ye, S. Ge, Understanding the importance of interaction between creators and backers in crowdfunding success, "Electronic Commerce Research and Applications" 2018, vol. 27, pp. 106-117; H. Zheng, B. Xu, T. Wang, Y. Xu, An Empirical Study Of Sponsor Satisfaction In Reward-Based Crowdfunding, "Journal of Electronic Commerce Research" 2017, vol. 18, no. 3, pp. 269-285. 
Trust is important aspect on the Internet market ${ }^{23}$, and in the case of crowdfunding, trust can be viewed as the multi-dimensional construct, which can include (at least): the brand of the project founder, the communication built by the elements of the crowdfunding film project website (for example, video, description of projects), and the brand of the crowdfunding platform on which the project is listed. In our study, the majority of respondents (over 65\%) stated that the film projects designed by filmmakers do not often engender trust in the potential backer (Table 4).

2. The respondents indicated the cultural barriers linked to the process of gathering funds.

Respondents highlighted that the project founder is often, first of all, a friend of the potential backers. This relationship, based on friendship, leads to psychological barriers - some kind of 'embarrassment' in a financial request being directed to a friend, as this request is perceived as being outside the space of friendship. As one of respondents stated: The process of funds gathering was connected with some kind of embarrassment and difficulty to ask friends for financial support. This 'awkwardness' or 'embarrassment' may explain why some members of crowdfunding project team withdrew from the process of funds gathering.

3. The respondents indicated that presentation of the unprofessional promotional video to the backers was a common a mistake.

Surprisingly, in our study the respondents claimed that the film project founders often make an unprofessional promotional video. The respondents' explanations of this paradox (that filmmakers who request support for their film on crowdfunding platforms cannot make a professional promotional video) were:

- the filmmaker, as a project founder does not have enough funding for the development of a crowdfunding project, including financing the making of a promotional video (the phases of development, production, and postproduction of the video);

- the project founder focuses on the artistic aspects of film making, and the filmmaker perceives the 'selling' aspect of the promotional video as not as important as the artistic film itself.

4. The respondents indicated that the crowdfunding project's lack of attractive rewards was a common mistake.

23 S. Grabner-Kraeuter, The Role of Consumers' Trust in Online-Shopping, "Journal of Business Ethics" 2002, vol. 39, no. 1/2, Four Teenth Annual Conference of the European Business Ethics Network (EBEN), pp. 43-50; D. Gefen, E-commerce: the role of familiarity and trust, "Omega" 2000, vol. 28, issue 6, pp. 725-737; D. H. McKnight, V. Choudhury, C. Kacmar, Developing and Validating Trust Measures for e-Commerce: An Integrative Typology, "Information Systems Research" 2002, vol. 13, no. 3, pp. 334-359; P. Kossecki, Kreowanie i pomiar wartości przedsiębiorstwa w świecie Internetu, Wydawnictwo Państwowej Wyższej Szkoły Filmowej, Telewizyjnej i Teatralnej im. L. Schillera w Łodzi, 2011. 
Over 65\% of respondents claimed that in many Polish film projects the tiers of rewards were wrongly developed. The majority of the film projects offer, among other options of rewards, the delivery of the film: DVD or online download. This type of reward is linked to sponsor's uncertainty about the quality of the final product, and this uncertainty can be lowered only in some cases, e.g. when the crowdfunding project is only for the post-production stage $e^{24}$.

However, the role which rewards play in attracting backers to the crowdfunding projects is still unclear. In our study, some respondents suggested that the rewards cannot play such a significant role in the backers' motivation as is commonly perceived (e.g. the respondent's statement: backing the project is not about the rewards at all). The respondents emphasized that backing for projects is more for the support of the art for art's sake or for friendship. Our findings seem to align with the view that the relationships built during the crowdfunding project are complex and cannot be simplified to the self-interest of backer or the altruistic motives ${ }^{25}$. However, the detailed analysis of the character and nature of these relationships was not captured in our study, and we perceived it as an interesting direction of further research.

Table 4. The mistakes made by film project founders on Polish market as indicated by respondents

\begin{tabular}{|l|c|}
\hline \multicolumn{1}{|c|}{ The mistake in the crowdfunding project } & $\begin{array}{c}\text { \% of respondents } \\
\text { indicating a statement as } \\
\text { common mistake in the } \\
\text { film projects }\end{array}$ \\
\hline 1 & 2 \\
\hline $\begin{array}{l}\text { The unprofessional video promoting the film on the } \\
\text { crowdfunding platform }\end{array}$ & 72.5 \\
\hline The film project does not engender trust in the backer & 67.5 \\
\hline Vague information about the budget spending & 65.5 \\
\hline Lack of rewards which can attract backers & 65.5 \\
\hline $\begin{array}{l}\text { There is no element distinguishing a project from other projects } \\
\text { on the crowdfunding platform }\end{array}$ & 65.0 \\
\hline
\end{tabular}

24 In some cases, especially when the film distribution is focused on film festivals, the final product as a reward is not offered to backers. For example, the experimental film 'Matka' ('Mother') which in 2017 successfully gathered the funds on the reward-based crowdfunding platform polakpotrafi.pl, offered the backers the possibility to watch the film at the cinema screening (premiere, the invited screening), some 'tangible' gifts connected with movie (e.g. storyboard, the poster), but not the final film product itself - see: Crowdfunding platform: polakpotrafi.pl, https://polakpotrafi.pl/projekt/matka-film-eksperymentalny/aktualnosci (accessed 18.03.2018).

25 See interesting publication - K. André, S. Bureau, A. Gautier, O. Rubel, op. cit. 
Table 4 (contd)

\begin{tabular}{|l|c|}
\hline \multicolumn{1}{|c|}{1} & 2 \\
\hline $\begin{array}{l}\text { Well-known people are not involved in the project (famous } \\
\text { directors, actors) }\end{array}$ & 60.0 \\
\hline High threshold level for film financing set by the project founders & 55.0 \\
\hline $\begin{array}{l}\text { Not enough information about the film project in the film } \\
\text { description put on the crowdfunding platform }\end{array}$ & 37.5 \\
\hline The theme of film (the plot) does not fit to the crowdfunding & 35.0 \\
\hline
\end{tabular}

Source: authors' own analysis.

\section{Conclusions, the limitations of the presented study and the future research}

Crowdfunding has gradually become more significant in the field of film funding, and in our opinion, this trend will be reinforced in the future. Using as a reference point the theoretical background of the process of adoption of innovation (Rogers's Diffusion of Innovation, TAM, UTAUT) we identified groups of specific factors influencing the rate of diffusion of this innovation. These factors are as follows:

1) Within the group of factors - 'the perceived usefulness and compatibility with existing values', the important issue hindering the process of the rate adoption is the perception that 'the professional filmmakers make the films by applying to the Polish Film Institute, not by crowdfunding'. Professionals within the film industry perceived crowdfunding as 'a useful tool, but mostly for beginners in filmmaking' due to:

a) the limit of achievable funding. However, our analysis of film projects suggests that, if global platforms were made available for the Polish project founders or Polish platforms would expand, the financial gap between crowdfunding and the traditional way of financing film production may be narrower than most of our respondents thought;

b) the respondents' negative perception of a situation where both professionals and non-professionals (or unexperienced filmmakers) are competing on the same platform. However, these beginners - unexperienced filmmakers - may constitute the future base of professional filmmakers and their experience with crowdfunding will shape its future implementation.

2) Another factor indicated within the group of 'compatibility with existing values' refers to the filmmakers' psychological reluctance to ask friends for 
financial support of the project. This aspect of results needs to be examined in a more detailed way in further research.

3) Within the group of factors - 'the complexity of innovation' - the following factors negatively affect the process of adoption:

a) the respondents indicated that both the potential sponsors and the filmmakers lack sufficient knowledge about crowdfunding;

b) the management of crowdfunding projects demands new skills and knowledge from the filmmakers compared to traditional film production;

c) the respondents stated that film project founders do not avoid mistakes in the film project, e.g. setting an unprofessional promotional video.

4) The factors linked to the complexity of crowdfunding which can have negative impact on rate adoption also include the aspect of team management - the management of the film crew involved in the crowdfunding campaign, for example: the personal and professional conflicts within the team, the multiple roles of a project founder.

5) The conducted study did not allow us to evaluate the moderating factors which have an impact on adoption rate, such as the years of experience in filmmaking. This aspect constitutes an interesting direction of future research.

The consistency of our results with the results of previous study conducted by U. Świerczyńska-Kaczor and P. Kossecki in $2016^{26}$, can be interpreted as a lack of significant changes of the role of crowdfunding for the last two years. It means that the process of diffusion of crowdfunding on Polish market can be slower than we anticipated when designing the study presented in this article.

So far, very few studies have explored crowdfunding and its impact on the Polish film industry. With so many 'unknowns' within the scope of the research problem, the applied qualitative approach can be assessed as adequate for our exploratory investigation. However, this approach is connected with (at least) the following limitations: the convenient sampling of respondents, the convenient sampling of analyzed case studies, and the subjectivity with interpretation of the respondents' statements.

Within the area of future research, we would like to point to the following topics.

- The study presented in this article highlights the following direction of future research: a) cultural aspects of building relationship between the backer and the founder, b) the analysis of created relationships within the whole ecosystem of the film-project, c) the challenges in the team management for the crowdfunding project, also for the projects with foreign co-producers.

- The conducted study takes into account factors impacting the adoption rate from the project founder perspective. Future research should shed more light on the second group: the backers/sponsors.

- Until now, the Polish film industry has lacked experience in the implementation of the investment-type crowdfunding (equity-based crowdfunding, and 
lending-based crowdfunding), and it is difficult to present how the investmenttype crowdfunding framework can be applied. However, the growing interest in crowdfunding and the discussion of its expansion ${ }^{27}$ may open new opportunities in the field of investment-type crowdfunding for creative industries, including filmmakers.

\section{Bibliography}

André K., Bureau S., Gautier A., Rubel O., Beyond the Opposition Between Altruism and Self-interest: Reciprocal Giving in Reward-Based Crowdfunding, "Journal of Business Ethics" 2017, vol. 146, issue 2, pp. 313-332.

Belleflamme P., Omrani N., Peitz M., The Economics of Crowdfunding Platforms, "Information Economics and Policy" 2015, vol. 33, pp. 11-28.

Cordova A., Dolci J., Gianfrate G., The Determinants of Crowdfunding Success: Evidence from Technology Projects, "Procedia - Social and Behavioral Sciences" 2015, vol. 181, pp. 115-124.

Crowdfunding platform Kickstarter, https://www.kickstarter.com/ [accessed 16.03.2018].

Crowdfunding platform Kickstarter, https://www.kickstarter.com/ [accessed 23.04.2018].

Crowdfunding platform: polakpotrafi.pl, https://polakpotrafi.pl/projekt/matka-film-eksperymentalny/aktualnosci [accessed 18.03.2018].

Crowdfunding platform Seedrs, https://www.seedrs.com/the-sleeping-room1 [accessed 23.04.2018].

Davis F. D., Bagozzi R. P., Warshaw P. R., User Acceptance of Computer Technology: A Comparison of Two Theoretical Models, "Management Science" 1989, vol. 35, no. 8, pp. 982-1003.

Dziuba D. T., Rozwój systemów crowdfundingu - modele, oczekiwania i uwarunkowania, „Problemy Zarządzania” 2012, vol. 10, nr 3 (38), pp. 83-103.

European Commission, Identifying market and regulatory obstacles to cross-border development of crowdfunding in the EU. Final report, December 2017, https:// ec.europa.eu/info/publications/171216-crowdfunding-regulatory-obstacles-c rossborder-development_en [accessed 23.04.2018].

Frydrych D., Bock A. J., Kinder T., Koeck B., Exploring entrepreneurial legitimacy in reward-based crowdfunding, "Venture Capital. An International Journal of Entrepreneurial Finance" 2014, vol. 16, issue 3, pp. 247-269.

27 For example, the publication - European Commission, Identifying market and regulatory obstacles to cross-border development of crowdfunding in the EU. Final report, December 2017, https://ec.europa.eu/info/publications/171216-crowdfunding-regulatory-obstaclescrossborder-development_en [accessed 23.04.2018]. 
Gabison G. A., Crowdfunding and its Regulation. How can Crowdfunding help ICT Innovation?, European Commission, EUR 26992 EN - Joint Research Centre - Institute for Prospective Technological Studies, 2015.

Gefen D., E-commerce: the role of familiarity and trust, "Omega" 2000, vol. 28, issue 6, pp. 725-737.

Grabner-Kraeuter S., The Role of Consumers' Trust in Online-Shopping, "Journal of Business Ethics" 2002, vol. 39, no. 1/2, Four Teenth Annual Conference of the European Business Ethics Network (EBEN), pp. 43-50.

Hörisch J., Crowdfunding for environmental ventures: an empirical analysis of the influence of environmental orientation on the success of crowdfunding initiatives, "Journal of Cleaner Production" 2015, vol. 107, pp. 636-645.

Kirby E., Worner S., Crowd-funding: An Infant Industry Growing Fast, Staff Working Paper of IOSCO Research Department [SWP3/2014], 2014.

Kordela D., Crowdfunding w Polsce - koncepcja finansowania społecznościowego, „Prace Naukowe Uniwersytetu Ekonomicznego we Wrocławiu” 2016, nr 436 (Rachunkowość na rzecz zrównoważonego rozwoju. Gospodarka - etyka - środowisko), pp. 143-153.

Kossecki P., Kreowanie i pomiar wartości przedsiębiorstwa $w$ świecie Internetu, Wydawnictwo Państwowej Wyższej Szkoły Filmowej, Telewizyjnej i Teatralnej im. L. Schillera w Łodzi, 2011.

Kozioł-Nadolna K., Crowdfunding jako źródło finansowania innowacyjnych projektów, „Zeszyty Naukowe Uniwersytetu Szczecińskiego. Finanse, Rynki Finansowe, Ubezpieczenia” 2015, nr 73 (Ryzyko, zarządzanie, wartość), pp. 671-683.

Kuti M., Madarász G., Crowdfunding, "Public Finance Quarterly" 2014, vol. 59, issue 3, pp. 355-366.

McKnight D. H., Choudhury V., Kacmar C., Developing and Validating Trust Measures for e-Commerce: An Integrative Typology, "Information Systems Research" 2002, vol. 13, no. 3, pp. 334-359.

Mollick E. (2014), The dynamics of crowdfunding: An exploratory study, "Journal of Business Venturing" 2014, vol. 29, issue 1, pp. 1-16.

Money.pl,Zrzutka.pl: Rynek crowdfundingu przekroczy 0,5 mld złw 2018 r., published: 06.02.2018, https:/www.money.pl/gielda/wiadomosci/artykul/zrzutka-pl-rynek-crowdfundingu-przekroczy,144,0,2397840.html [accessed 01.04.2018].

Polish Film Institute, PISF, https://www.pisf.pl/ [accessed 15.03.2018).

Polish Film Institute, PISF: https://www.pisf.pl/dotacje/dofinansowane-projekty/2017/ po-produkcja-filmowa/priorytet-4-filmy-dokumentalne-sesja-1-2017) [accessed 15.03.2018].

Regulation (EU) 2016/679 of the European Parliament and of the Council of 27 April 2016 on the protection of natural persons with regard to the processing of personal data and on the free movement of such data, and repealing Directive 95/46/EC (General Data Protection Regulation), Official Journal of the European Union, 2016.119.1. 
Rogers E. M., Diffusion of Innovations, 5th Edition, Free Press, 2003.

Steigenberger N., Why supporters contribute to reward-based crowdfunding, "International Journal of Entrepreneurial Behavior \& Research” 2017, vol. 23, issue 2, pp. 336-353.

Świerczyńska-Kaczor U., Kossecki P., The Role of Polish Crowdfunding Platforms in Film Productions - an Exploratory Study, "Proceedings of the 2016 Federated Conference on Computer Science and Information Systems, Annals of Computer Science and Information Systems” 2016, vol. 8, pp. 1289-1296.

Thürridl C., Kamleitner B., What Goes around Comes Around? Rewards as Strategic Assets in Crowdfunding, "California Management Review" 2016, vol. 58, issue 2, pp. 88-110.

Ustawa z dnia 18 lipca 2002 r. o świadczeniu usług drogą elektroniczną, Dz.U. 2002, Nr 144, poz. 1204.

Venkatesh V., Morris M. G., Davis G. B., Davis F. D., User Acceptance of Information Technology: Toward a Unified View, "MIS Quarterly" 2003, vol. 27, no. 3, pp. 425-478.

Wang N., Li Q., Liang H., Ye T., Ge S., Understanding the importance of interaction between creators and backers in crowdfunding success, "Electronic Commerce Research and Applications” 2018, vol. 27, pp. 106-117.

Zheng H., Xu B., Wang T., Xu Y., An Empirical Study Of Sponsor Satisfaction In Reward-Based Crowdfunding, "Journal of Electronic Commerce Research" 2017, vol. 18, no. 3, pp. 269-285.

\section{Analiza jakościowa czynników wpływających na poziom akceptacji crowdfundingu opartego na nagrodach przez polskich filmowców}

Streszczenie: Celem artykułu jest analiza i omówienie czynników wpływających na proces implementacji crowdfundingu przez polski sektor filmowy. Zaprezentowane w artykule badania zostały oparte na metodach jakościowych: nieustrukturalizowanych lub częściowo ustrukturalizowanych wywiadach i kwestionariuszach oraz na analizie studium przypadków. Respondenci wskazali i dokonali ewaluacji szerokiego spektrum czynników wspierających i hamujących proces akceptacji innowacji, jaką jest crowdfunding: od ogólnych barier (np. legislacji prawnych dotyczących crowdfundingu), po czynniki ściśle związane z produkcją filmową (np. nieprofesjonalne wideo promujące projekt crowdfundingowy). Wyniki badań podkreślają szczególne znaczenie następujących czynników: silnej postawy respondentów oceniającej crowdfunding jako narzędzie dla początkujących filmowców, złożoność procesu zarządzania zespołem (ekipą filmową) w trakcie realizacji projektu kampanii crowdfundingowej oraz aspekt kulturowy dotyczący szukania wsparcia dla projektu wśród grona znajomych.

Słowa kluczowe: innowacja finansowania filmu, projekt crowdfundingowy, finansowanie filmu. 